\title{
Radek ČADA*, Jan ZLÁMALÍ́K** \\ PROJECT OF ECONOMICALLY PROFITABLE TECHNOLOGICAL PROCESS OF PRODUCTION OF ROTOR AND STATOR PLATES OF INDUCTIVE POSITION SENSOR BY BLANKING AND ROLL BENDING
}

\author{
NÁVRH EKONOMICKY VÝHODNÉHO TECHNOLOGICKÉHO PROCESU VÝROBY \\ ROTOROVÝCH A STATOROVÝCH PLECHŮ INDUKČNÍHO SNÍMAČE POLOHY \\ VYSTŘIHOVÁNÍM A ZKRUŽOVÁNÍM
}

\begin{abstract}
Paper concerns innovation of production of rotor and stator plates of inductive position sensors which are used at automatization of production processes. Authors analyse possibility of efficiency improvement of production of these devices in joint-stock company TES VSETÍN and suggest concrete solving of new production technology. Composition of production line for blanking and roll bending of rotor and stator plates of inductive position sensor from individual technological devices was suggested: decoiler, straightening device, actuating belt feeder, pneumatic shears with inclined tools, belt conveyer and four cylinders bending rolls. Construction of production line was projected in order to its operation can be secured by one production workman, which controls and chooses operation of CNC programme, takes separate roll bended rotor and stator plates of inductive position sensor from bending rolls and according to required technological procedure he composes them to rotor and stator complexes. Construction of production line was projected so that it is possible to move it by crane without necessity to dismantle and subsequently to put together and adjust the line.
\end{abstract}

\begin{abstract}
Abstrakt
Článek se týká inovace výroby rotorových a statorových částí indukčních snímačů polohy, které se uplatňují při automatizaci výrobních procesů. Autoři rozebírají možnost zefektivnění výroby těchto přístrojů ve firmě TES VSETÍN, a. s., a navrhují konkrétní řešení nové výrobní technologie. Bylo navrženo sestavení výrobní linky pro vystřihování a zkružování rotorových a statorových plechů indukčního snímače polohy z jednotlivých technologických zařízení: odvíjecího zařízení, rovnacího zařízení, válečkového servopodavače, pneumatických nůžek se skloněnými noži, pásového dopravníku a čtyřválcové zakružovačky. Konstrukce výrobní linky byla navržena tak, aby její obsluha byla zabezpečena jedním výrobním dělníkem, který ovládá a volí chod $\mathrm{CNC}$ programu, odebírá jednotlivé zkružené rotorové a statorové plechy indukčního snímače polohy ze zakružovačky a dle předepsaného technologického postupu je skládá do rotorových a statorových celků. Konstrukce výrobní linky byla navržena tak, že ji lze přemistovat pomocí jeřábu, aniž by bylo nutno linku demontovat a následně znovu sestavovat a seřizovat.
\end{abstract}

* prof. Ing. Radek Čada, CSc., VŠB - Technical University of Ostrava, Faculty of Mechanical Engineering, Department of Mechanical Technology, 17. listopadu 15, 70833 Ostrava-Poruba, Czech Republic, tel.: +42059 7323289, fax: +420596916490, e-mail: radek.cada@ vsb.cz

** Ing. Jan Zlámalík, VŠB - Technical University of Ostrava, Faculty of Mechanical Engineering, Department of Mechanical Technology, 17. listopadu 15, 70833 Ostrava-Poruba, Czech Republic, tel.: +420 59 7323289, fax: +420 59 6916490, e-mail: jan.zlamalik.st@ vsb.cz 


\section{INTRODUCTION}

In all the technically advanced countries the rapid development of automation is apparent. Flawless management of automated systems requires to have enough data on the managed element. To capture and control the rotation of various rotating mechanical parts of machines the position sensors are used.

\section{POSITION SENSORS}

\subsection{Purpose and types of position sensors}

The control of position is one of the most widespread use of position sensors. Measurement of speed is quite common and necessary task in the industry. For example it is control of the angular velocity of motors, shafts, gear sets, generators and other rotating parts of machinery, measuring circumferential speed of these components, as well as conveyor belt feed speed or rotation of the blades in machine units.

Position sensing can be carried out by contact or non-contact measurement:

- Contact measurement of speed can be realized by sensors that record the rotational motion of a shaft or pulley by turning the injection. Peripheral speed can be monitored by attaching of sensing wheel to wheel circumference or pulley. Sensing wheel can also be used for sensing of linear movement of, for example, the belt displacement.

- Non-contact measurement of speed and direction of machine components can be carried out by a light beam, optoelectronics, electromagnetic induction, capacity change, etc. Among the non-contact measuring devices the include inductive position sensors rank.

\subsection{Principle, description and use of inductive position sensor}

Inductive position sensor (Fig. 1.1), also called the resolver, or rotary transformer, the absolute induction meters with analog output. Because they are based on the principle of electromagnetic induction, they contain primary and secondary windings. The primary winding is wound on the rotor (see 1.2.1), so it is fixed to the shaft, which angle or rotation speed measures. The primary winding is connected to a source of sinusoidal voltage with a frequency of about 2 to $10 \mathrm{kHz}$. Secondary windings which are located in the stator (see 1.2.2) are mutually spatially rotated by $90^{\circ}$. Wiring diagram is shown in Fig. 1.2.

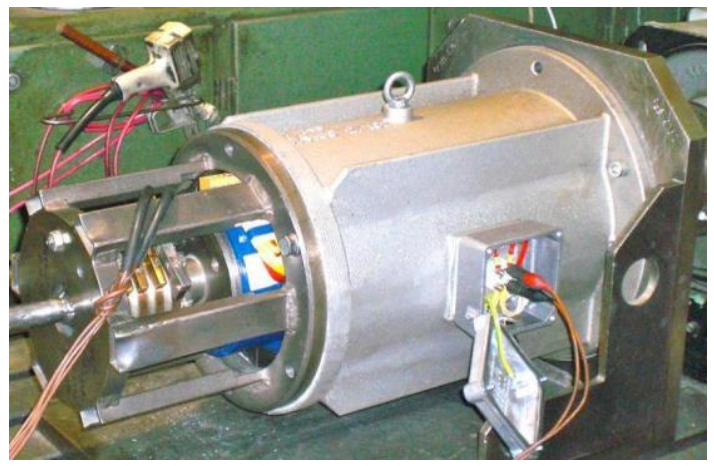

Fig. 1.1 Inductive position sensor

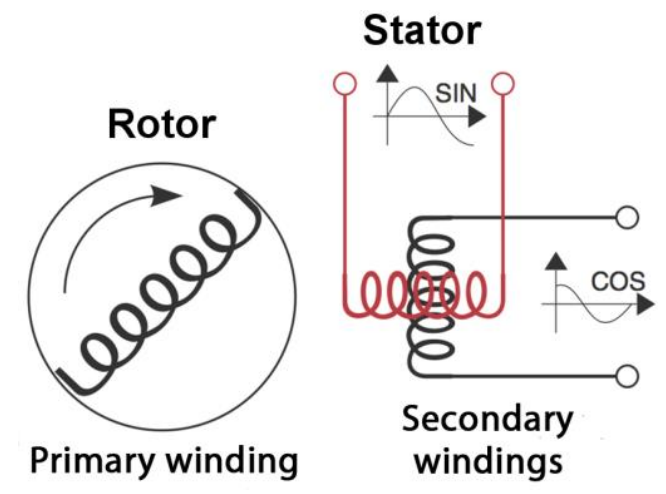

Fig. 1.2 Wiring diagram of inductive position sensor

Information about the angle of the shaft (rotor) is obtained according to the signal that is proportional to the sine and cosine of rotor angle. Every angle of the shaft corresponds to a different combination of output variables.

Nowadays resolvers are often mounted directly to the engines (see Fig. 1.3), thus gaining power unit with built-in encoder. This eliminates the additional inductive sensor assembly to the 
motor shaft. Small motors containing resolvers are used for example in robotic arms (Fig. 1.4) and NC machines.

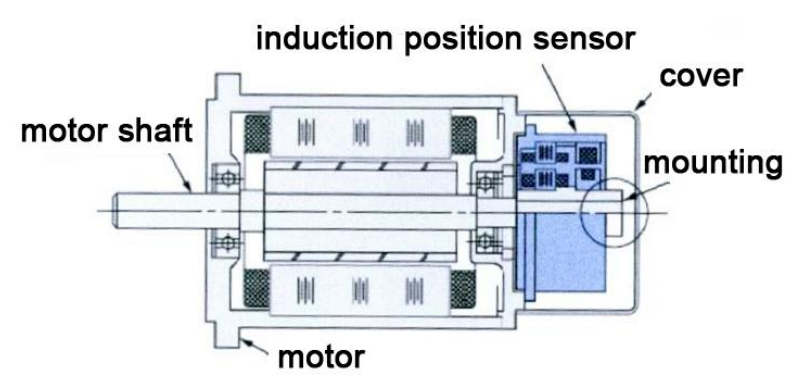

Fig. 1.3 Combination of inductive position sensor with the engine

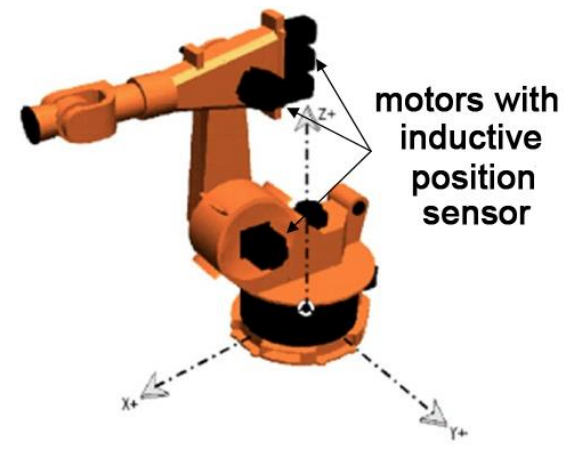

Fig. 1.4 Example of using inductive position sensor in robotic arms

\subsubsection{Description of induction position sensor rotor}

Induction position sensor rotor is mounted on the shaft and takes with him a rotary motion. The rotor has the form of a cylinder, which is formed for electrical sheets with special electromagnetic properties.

Inductive position sensor rotor (Fig. 1.5), produced in joint-stock company TES VSETÍN, is made according to the requirements from 12 pieces of electrical sheets with dimensions of $170 \times 438 \mathrm{~mm}$, followed by 13 pieces of plates with dimensions of $170 \times 478 \mathrm{~mm}$ and 1 piece of sheet with dimensions of $170 \times 515 \mathrm{~mm}$. These plates are roll bended and then assembled according to the technological regulation in sintering apparatus (see Fig. 1.6). The rotor plates are from one side insulated by varnish with the name Backlak which allows gluing of separate curved plates, and on the other side by varnish with the name Remisol. These varnishes are used as insulators and prevent the loss by whirling flows. Sintering preparations with plates are then placed in an oven where the plates are at the temperature $220^{\circ} \mathrm{C}$ glued together. By this gluing the single rotor complex arises.

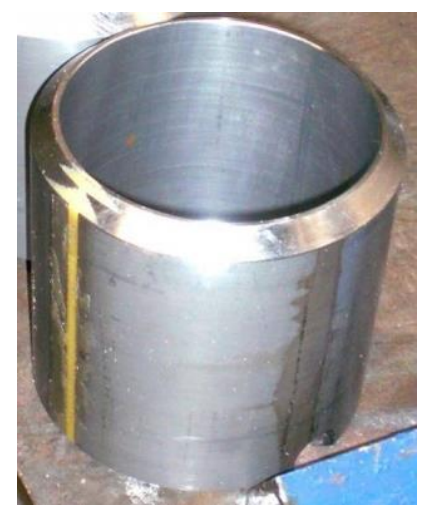

Fig. 1.5 Rotor complex of inductive position sensor

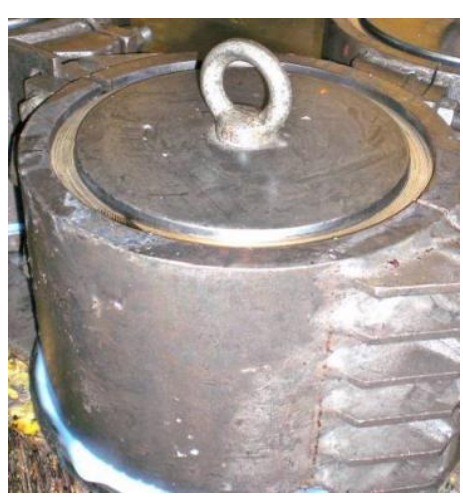

Fig. 1.6 Sintering apparatus with plates prepared for gluing

\subsubsection{Description of inductive position sensor stator}

Inductive position sensor stator is its immobile (static) part. Into the stator the rotor is inserted (see 1.2.1), where the distance between these two parts, the air gap, has an influence on the electromagnetic properties of the sensor. 
Inductive position sensor stator (Fig. 1.7), produced in joint-stock company TES VSETÍN, is made according to the requirements from 12 pieces of electrical sheets with dimensions of $170 \times 656 \mathrm{~mm}$, followed by 10 pieces of plates with dimensions of $170 \times 690 \mathrm{~mm}, 6$ pieces of plates with dimensions of $170 \times 702 \mathrm{~mm}$ and 1 piece of sheet with dimensions of $170 \times 735 \mathrm{~mm}$. The stator plates have the same electromagnetic properties as the rotor plates. These plates are roll bended and then assembled according to the technological regulation in sintering apparatus (see Fig. 1.6). The stator plates are like rotor plates from one side insulated by varnish with the name Backlak which allows gluing of separate curved plates and on the other side by varnish with the name Remisol. These varnishes are used as insulators and prevent the loss by whirling flows. Sintering preparations with plates are then placed in an oven where the plates are at the same temperature as the rotor plates, i.e. $220^{\circ} \mathrm{C}$, glued together. By this gluing the single stator complex arises, which is inserted into the cage of the whole inductive position sensor.

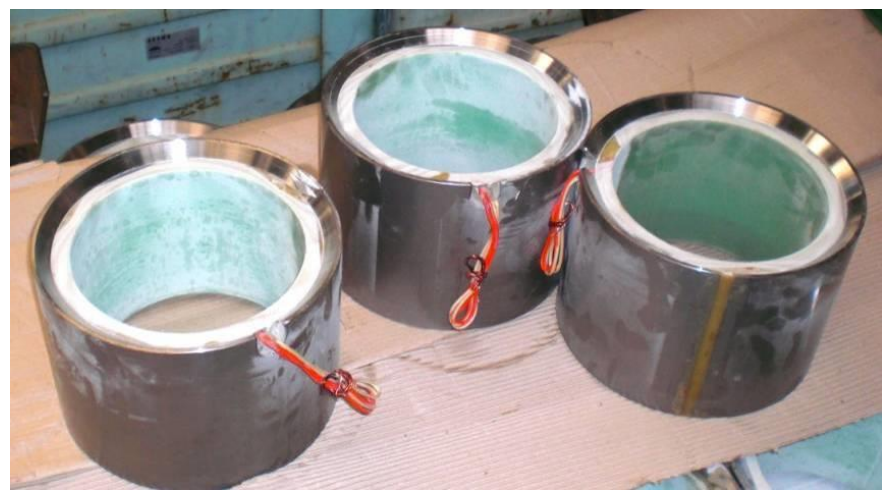

Fig. 1.7 Stators of inductive sensor with winding

\subsection{Selection of the right material for inductive position sensor}

In order to ensure maximum efficiency of inductive position sensor the analysis of properties of separate sheet-metal and strips intended for electronics, i.e. isotropic alloyed cold-rolled steels in semi-finished state, oriented transformer cold-rolled steels, isotropic electrical cold-rolled steels in the fully processed state and the silicon cold-rolled steels. From analysis concluded that the most suitable material is the sheet from isotropic electrical cold-rolled steel for electrical engineering in the fully processed state M400-50A according to EN 10106. Plates are supplied with an organic insulation Sulfizol or inorganic varnish Remisol.

\section{CURRENT PRODUCTION TECHNOLOGY OF ROTOR AND STATOR PLATES}

Current production technology of plates for rotors and stators of inductive position sensor (see 1.2) is in the joint-stock company TES VSETÍN carried out in four steps at four different workplaces.

Plates from which the inductive position sensors are manufactured are supplied in coils with width of $1000 \mathrm{~mm}$. These coils are according to the technological regulation cut to plates by twopoint eccentric press ZDAZ LKD 400 (see Fig. 2.1). For induction position sensor rotor the dimensions of plates $448 \times 1000 \mathrm{~mm}, 488 \times 1000 \mathrm{~mm}$ a $525 \times 1000 \mathrm{~mm}$ are required, for the stator the dimensions of plates $666 \times 1000 \mathrm{~mm}, 700 \times 1000 \mathrm{~mm}, 712 \times 1000 \mathrm{~mm}$ a $745 \times 1000 \mathrm{~mm}$ (see tab. 2.1 and tab. 2.2) are required. Number of required plates in mentioned dimensions is given by the produced number of units of inductive position sensors. On each plate with a width of $1000 \mathrm{~mm}$, which is the width of the coil, five pieces of clippings with width of $170 \mathrm{~mm}$ can be placed, which is the prescribed length of the inductive position sensor.

Separate sheet plates with given dimensions are further moved to the exact cut out of prescribed dimensions of strips to hydraulic plate shears Amada GPN 630 (see Fig. 2.2). 
Tab. 2.1 Dimensions and number of pieces of sheet strips for production of inductive position sensor rotor

\begin{tabular}{|c|c|c|}
\hline $\begin{array}{c}\text { Sheet plate dimensions } \\
(\mathbf{m m})\end{array}$ & $\begin{array}{c}\text { Sheet strip dimensions } \\
(\mathbf{m m})\end{array}$ & $\begin{array}{c}\text { Number of sheet strips for production } \\
\text { of one inductive position sensor (pcs) }\end{array}$ \\
\hline \hline $448 \times 1000$ & $170 \times 438$ & 12 \\
\hline $488 \times 1000$ & $170 \times 478$ & 13 \\
\hline $525 \times 1000$ & $170 \times 515$ & 1 \\
\hline
\end{tabular}

Tab. 2.2 Dimensions and number of pieces of sheet strips for production of inductive position sensor stator

\begin{tabular}{|c|c|c|}
\hline $\begin{array}{c}\text { Sheet plate dimensions } \\
(\mathbf{m m})\end{array}$ & $\begin{array}{c}\text { Sheet strip dimensions } \\
(\mathbf{m m})\end{array}$ & $\begin{array}{c}\text { Number of sheet strips for production } \\
\text { of one inductive position sensor (pcs) }\end{array}$ \\
\hline \hline $666 \times 1000$ & $170 \times 656$ & 12 \\
\hline $700 \times 1000$ & $170 \times 690$ & 10 \\
\hline $712 \times 1000$ & $170 \times 702$ & 6 \\
\hline $745 \times 1000$ & $170 \times 735$ & 1 \\
\hline
\end{tabular}

The next step in the current production technology of rotor and stator plates of inductive position sensor is roll bending of separate cut sheet strips to specified dimensions, which is performed on a motor-driven three rolls roll bending machine Roundo PAS-360 (see Fig. 2.3). Separate sheet strips are set up to roll bending machine manually. Roll bending is performed in two passes of sheet strip, when in the first pass the sheet is roll bended to the desired diameter and by the second passage this sheet is calibrated, thereby reducing the cushioning of roll bended sheet. Adhesive side of the sheet, which is equipped with varnish Backlak, must be on the outer diameter of a roll bended sheet strip except the sheet strip for the rotor with dimensions of $170 \mathrm{x} 438 \mathrm{~mm}$ and for the stator with dimensions of $170 \times 735 \mathrm{~mm}$, where the sticky side of sheet strip that is fitted with varnish Backlak, must be on the inner side of a roll bended sheet strip. In order the grease was not on separate strips and by that to avoid the disruption of the protective coating, it is necessary to handle sheets with gloves.

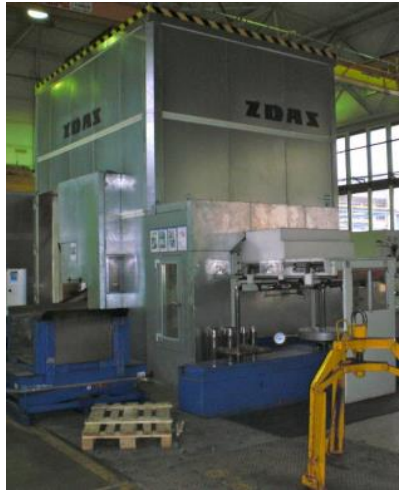

Fig. 2.1 Two-point eccentric press ZDAZ

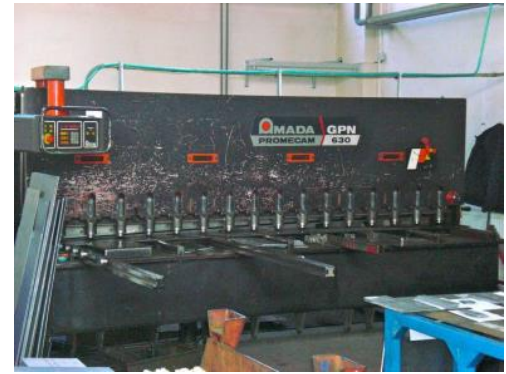

Fig. 2.2 Hydraulic plate shears Amada GPN 630

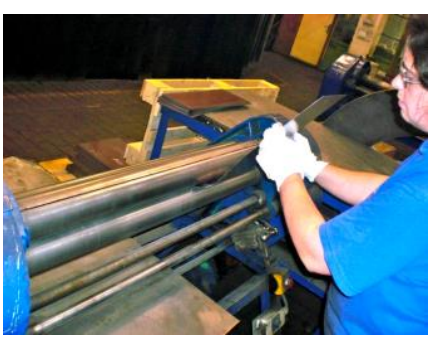

Fig. 2.3 Motor-driven roll bending machine Roundo PAS-360

\section{LKD 400}

The last step in the existing production technology is the insertion of separate roll bended strips according to their lengths to sintering apparatus (see Fig. 1.6). Sintering preparations with plates are then inserted into the furnace, where at temperature of $220^{\circ} \mathrm{C}$ for 10 minutes separate roll 
bended strips glued together by varnish Backlak. The gap between roll bended ends of the plates is subsequently embedded by two-component epoxy, in which the silicon is used as a filler (see Fig. 2.4 and 2.5). This epoxy is cured at a temperature of about $80^{\circ} \mathrm{C}$ by which the stator and rotor packets (see Fig. 2.6) of inductive position sensor arise, which are then passed to the next technological and assembly operations.

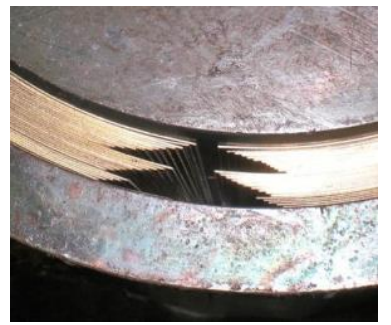

Fig. 2.4 Gap between the ends of roll bended strips before flooding by the two-component epoxy

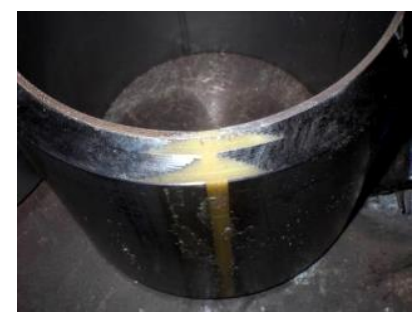

Fig. 2.5 Gap between the ends of roll bended strips after flooding by the twocomponent epoxy

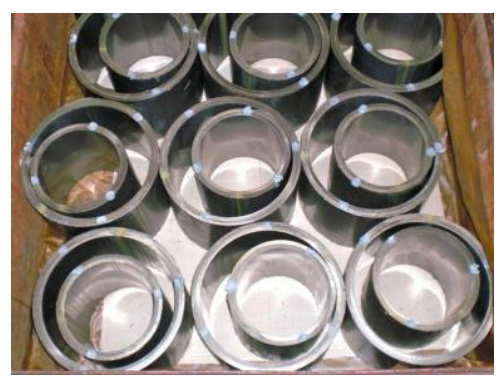

Fig. 2.6 Stator and rotor packets of inductive position sensor

\section{PROPOSAL OF ECONOMICALLY ADVANTAGEOUS TECHNOLOGICAL PRODUCTION PROCESS OF ROTOR AND STATOR PLATES}

The aim of proposal of economically advantageous technological production process of rotors and stators of inductive position sensor in joint-stock company TES VSETÍN was to increase productivity by $20 \%$ compared with current conditions (see tab. 3.1). By suitable design of technologies of cutting and roll bending and by grouping of separate production workplaces into the production line the rationalization of production was achieved.

Tab. 3.1 Production of rotor and stator units of inductive position sensor per year

\begin{tabular}{|c|c|c|}
\hline $\begin{array}{c}\text { Produced } \\
\text { part }\end{array}$ & $\begin{array}{c}\text { Total number of plates required } \\
\text { for production of one unit (pcs) }\end{array}$ & $\begin{array}{c}\text { Number of inductive position } \\
\text { sensors per one year } \boldsymbol{p} \text { (pcs) }\end{array}$ \\
\hline rotor unit & 26 & 3600 \\
\hline stator unit & 29 & 3600 \\
\hline inductive position sensor & 55 & 3600 \\
\hline
\end{tabular}

\subsection{Proposal of effective technology of cutting rotor and stator plates}

Based on the analysis of metal cutting technology, i.e. cutting by parallel cutting knives, cutting by angled knives, cutting by circular knives and cutting by rubber, utilization of technology of cutting by angled knives for the production of rotor and stator plates of inductive position sensor was proposed. This technology makes possible to achieve the necessary precision of sheet-metal cutting, when the size of burr of cut edge that is in electrical engineering the decisive parameter must not exceed $10 \%$ of the thickness of cut sheet. Another advantage of this technology is the need of smaller cutting force and the elimination of shocks than when using technology of cutting by parallel cutting knives. Disadvantage in terms of deformation of the waste material was proposed to eliminate by the use of blankholder at cutting of the material.

\subsection{Proposal of appropriate technology of roll bending of rotor and stator plates}

For roll bending of rotor and stator plates, which forms the main part of the inductive position sensor, after analyzing the types of bending machines using of four-cylinder rolling was designed. 
When using this technology it is possible to produce roll bended sheet in one pass without causing non bended plates ends. Using of three-roller symmetrical bending rolls is not appropriate, because it would be necessary to eliminate the separate plates ends non bending by roll bending by two passages, which is time-inefficient.

Utilization of four-cylinder bending rolls allows to place the separate technological operations in chronological order according to the technological process and automate the entire process.

\subsection{Proposal of production line for cutting and roll bending of rotor and stator plates}

To streamline the production of rotor and stator plates by cutting and roll bending the combination of the proposed technologies in incremental production line (see Fig. 3.1) and automation of the entire production process were proposed.

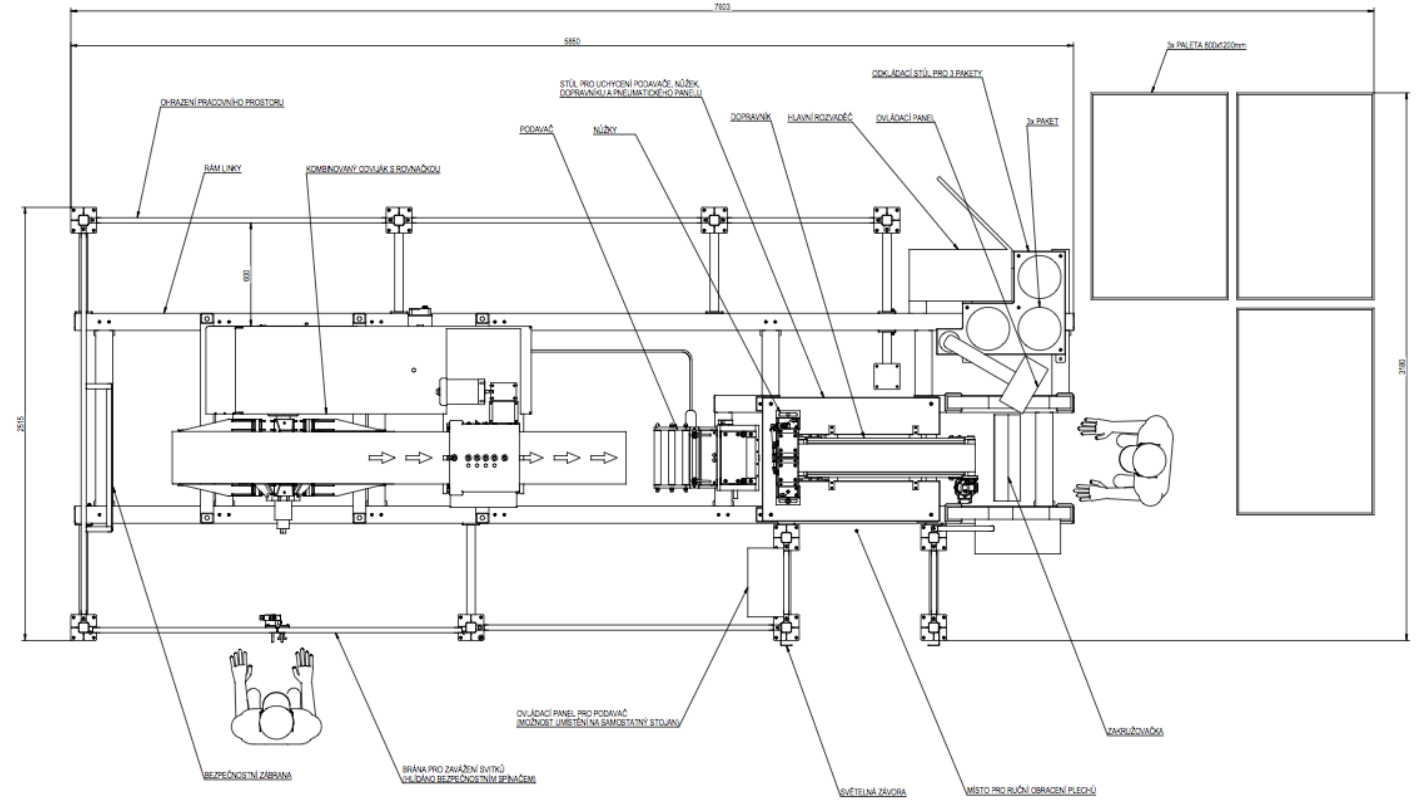

Fig. 3.1 Diagram of line for cutting and roll bending of plates for production of rotor and stator plates of inductive position sensor

\subsubsection{Functional description of the production line of rotor and stator plates}

Designed sheet M400-50A EN 10106 (see 1.3.3) for production of rotor and stator plates comes to production line in the form of sheet coils. To allow the use of automated production of rotor and stator plates, the authors designed coil width of $170 \mathrm{~mm}$. The coil is placed in the production line to the unwinding device. Sheet, which is unwound from the unwinding device, enters the straightening device, which eliminates the deflection of sheet, which may result in twisting of the sheet coil. Sheet then enters the feeding device that controls by the CNC program the length of sheet strip feed, which is inserted to pneumatic shears. In the pneumatic shears the sheet strip is cut off from the coil and is transferred to the belt conveyor that moves the sheet cut to the lengths prescribed by the program into the turntable, where according to the program only goes to either roll bending or is rewound and then introduced into roll bending. 


\subsubsection{Choice of technological components of the production line}

For efficient production of rotor and stator plates of inductive position sensor the assembly of production line from these technological devices (see Fig. 3.2) was designed:

a) decoiler,

b) straightening device,

c) actuating belt feeder,

d) pneumatic shears with inclined tools,

e) belt conveyer,

f) four cylinders bending rolls.

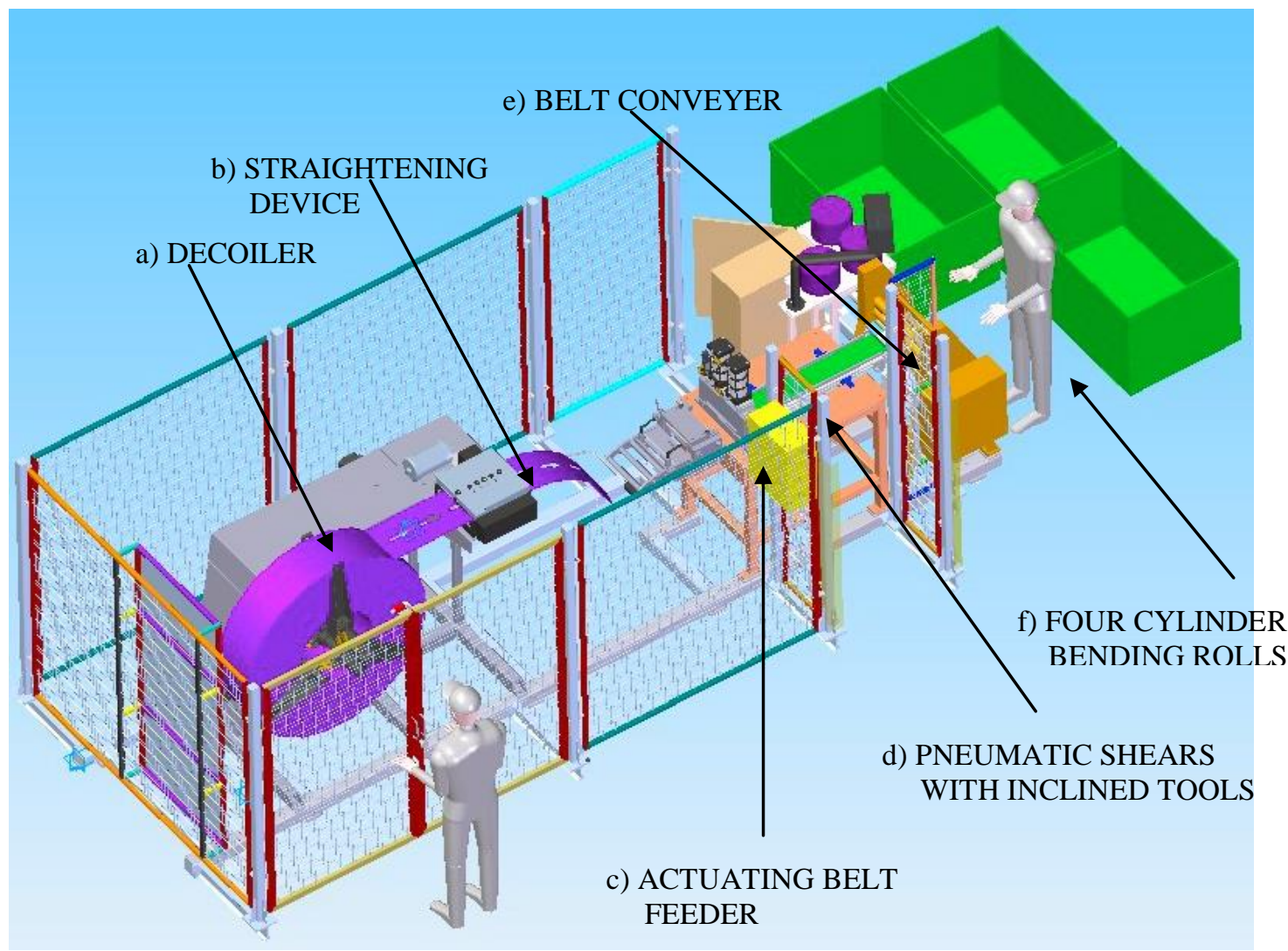

Fig. 3.2 Proposed line for the production of rotor and stator plates of inductive position sensor with the deployment of technological equipment

a) Decoiler (see Fig. 3.3) ensures smooth supply of required quantity of sheet strip to pneumatic shears. Body of decoiler consists of a stable welded construction, on which is also the straightening device is located. Coil of sheet strip with the proposed width of $170 \mathrm{~mm}$ is based on the mechanical expansion mandrel. Decoiler is not powered by a motor, so scroll unwound by pulling material realized by straightening machine. To prevent spontaneous unwinding of strip on the unwinding shaft the mechanical brake is mounted. Access to adjust bolt of brake is carried out through the assembly door in the frame. When properly adjusted unwinding device brake no spontaneous unwinding arises and the material is between the decoiler and the straightening equipment in tightened state.

Material loop (see Fig. 3.4) between the straightening device and the feeder is used for evenly and continuously feeding of material into the pneumatic shears. Decoiler is equipped with a swinging arm resting on the belt plate. Sensing loop using the swingarm is the simplest and cheapest system. Swingarm is placed on a strip of material and shortening or lengthening the loop performs 
an oscillating motion. The arm is fitted with clamp connections on the grooved shaft transducer and its movement is transmitted to the drive actuator potentiometer straighteners. When mounting the arm to be fitted on the spline shaft so that the horizontal position of the shaft at the end of its rotary movement and therefore the tension to activate the safety switch and stopping the line.

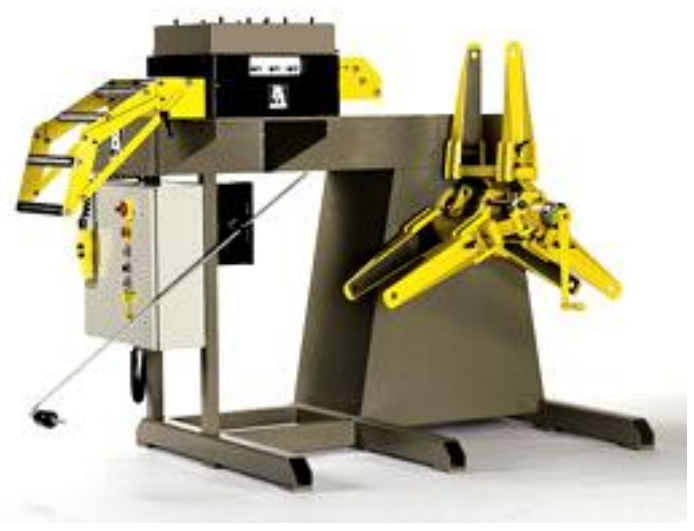

Fig. 3.3 Decoiler associated with straightening device

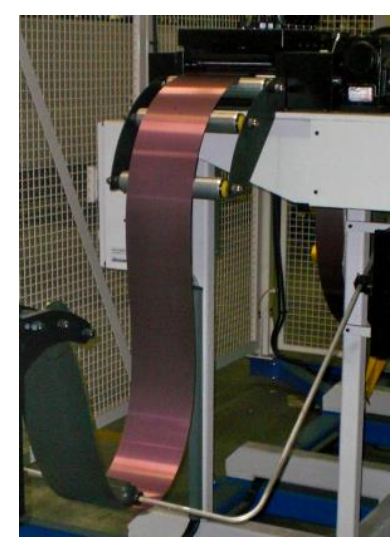

Fig. 3.4 Material loop with rocker

b) Straightening device (see Fig. 3.5) is used to remove undesirable distortions caused by the twisting metal into coils. Material that scroll from the coil enters the straightening device, where it passes between the upper and lower row of cylinders with diameter of $38 \mathrm{~mm}$. In the bottom line 5 cylinders is stored in the upper range 4 cylinders. All rollers are hardened to $60 \mathrm{HRC}$ and then are finely ground. To adjust the straightening device the set of upper cylinders is individually adjustable. Straightening rollers must be adjusted so that the front, where the material enters into the straightening device, to the back, where the material exits from the straightening device, bringing fewer straightening work, i.e. its immersion into the material shrunk. Setting values of individual cylinders can be read on centesimal watches, which are part of the device. With proper adjustment based straightening equipment belt out slightly downward curved or straight. If the material is not enough to offset the need to further reduce the straightening rolls. If the material is based on curved upwards, the straightening rolls must be released back.

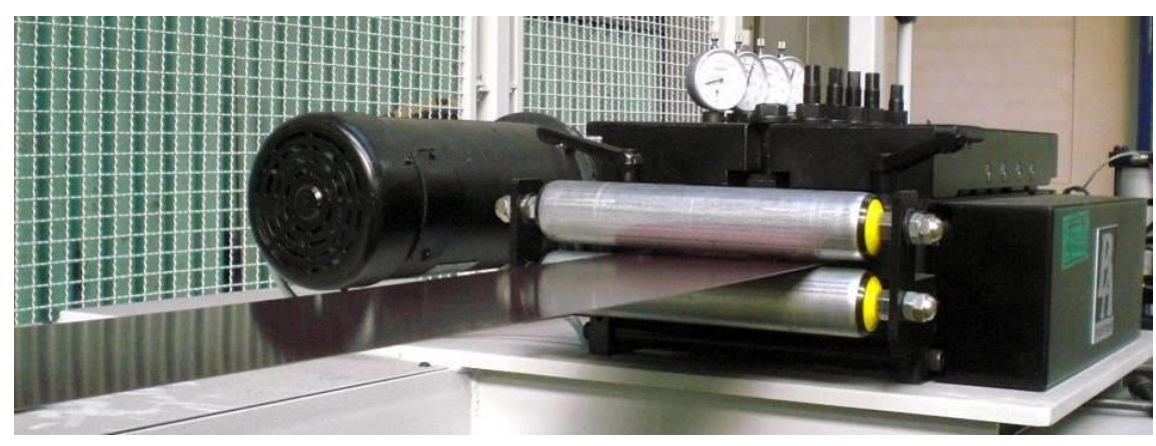

Fig. 3.5 Straightening machine with centesimal watches

c) Actuating belt feeder (see Fig. 2.14) carries out the length of the plate according to the CNC program to pneumatic shears with inclined tools. Accuracy of material feeding is $\pm 0.025 \mathrm{~mm}$. Actuating belt feeder consists of finely ground hardened rollers lightweight structures, which are stored in a maintenance-free ball bearings. Synchronous operation of the upper and lower cylinder is operating with gears without tooth will. Actuating belt feeder has leading wirings with manually adjustable side scrolls. This flow management has the task easier and more precise guidance of the sheet strip to the actuating belt feeder. 
d) Pneumatic shears with inclined tools (Fig. 2.15) are used for cutting of sheet-metal strip. Material feed to the desired length is realized by roller actuating belt feeder. Shears are powered by compressed air and to activate the working stroke need an electrical signal. The pneumatic cylinder is controlled by four-way solenoid valve. Using the signal from terminal sensor, inductive sensor, camshaft sensor and programmable timing relays can be synchronized with any shearing machine. To prevent deformation of the material during cutting, shearing is used grippers. This is achieved with a clean cutting edge burr size up to $10 \%$ of the thickness of the sheared material. Shearing blades, i.e. the upper blade and lower blade, having all four edges of the shear, which means that one blunt edge and can be rotated to work with the cutting edge of the next. If all four cutting edges are dulled, the knife must be sharpened. Shears structure is anchored to a stable steel frame. Keeping the upper blade against the lower blade is secured by guideposts with bronze bearing shells.

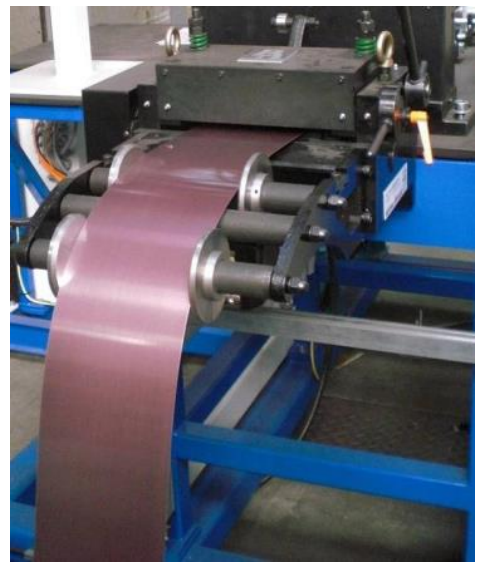

Fig. 3.6 Actuating belt feeder

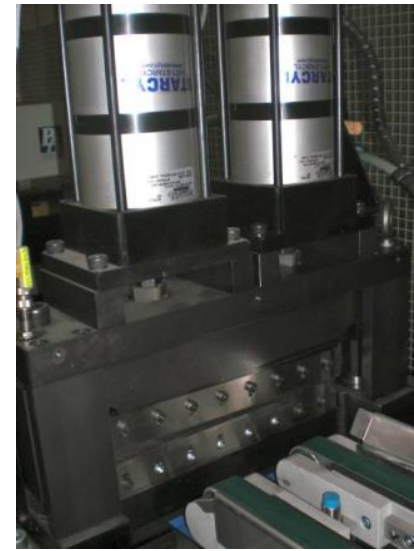

Fig. 3.7 Pneumatic shears with inclined tools

e) Belt conveyer is used for transport of the cut sheet strip to bending rolls. For better introduction of cut sheet strip to bending rolls the apparatus was designed which after leaving the plate from the conveyer belt guides this material to bending rolls (see Fig. 3.8).

f) Four-cylinder bending rolls (see Fig. 3.9) has an asymmetrical arrangement of the rollers and allows to produce a bend rolled sheet in one pass without causing non bending of the plates ends. To ensure high durability of rolling cylinders their heat treatment by quenching was proposed.

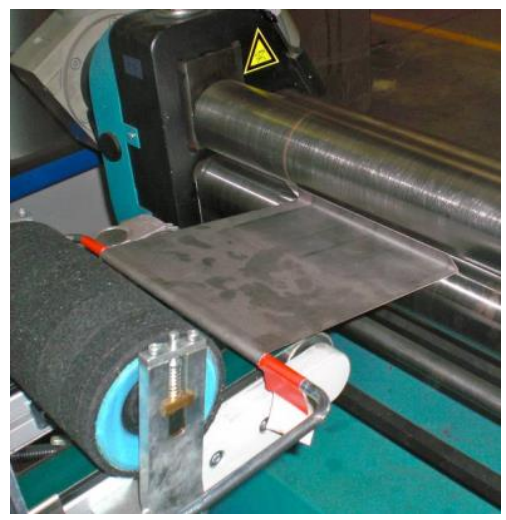

Fig. 3.8 Preparation for direct the strip to the bending rolls

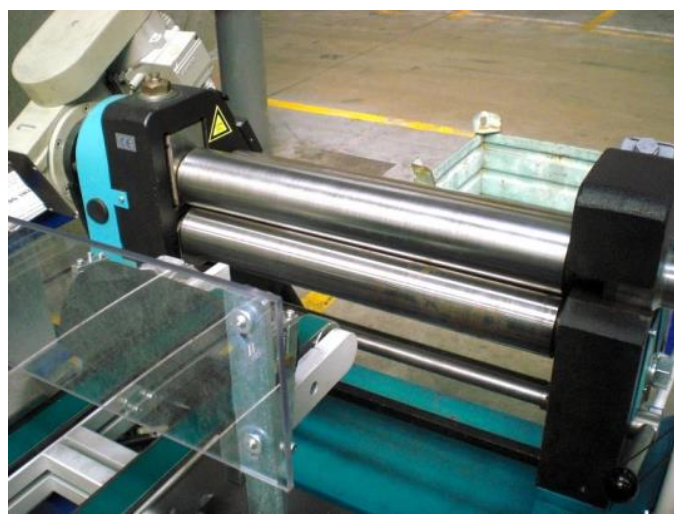

Fig. 3.9 Four-cylinder bending rolls of the production line 
Operation of the production line can be secured by one manufacturing worker, who controlled it using CNC program and also removes separate curved stator and rotor plates of inductive position sensor from bending rolls and according to the prescribed technologic procedure he consists them to the rotor and stator units.

To ensure the safety of production workers and people moving close to the production line, the security of production line by protective fence, that prevents the access to the workspace, was proposed. To replace the sheet coil the access through gate is allowed, which is guarded by a closing door safety switches.

\section{CONCLUSIONS}

Based on the analysis of metal cutting technology utilization of technology of cutting by angled knives for the production of rotor and stator plates of inductive position sensor was proposed (see 3.1). This technology makes possible to achieve the necessary precision of sheet-metal cutting, when the size of burr of cut edge that is in electrical engineering the decisive parameter must not exceed $10 \%$ of the thickness of cut sheet. Another advantage of this technology is the need of smaller cutting force and the elimination of shocks than when using technology of cutting by parallel cutting knives. Disadvantage in terms of deformation of the waste material was proposed to eliminate by the use of blankholder at cutting of the material.

For roll bending of rotor and stator plates, which forms the main part of the inductive position sensor, after analyzing the types of bending machines using of four-cylinder rolling was designed (see 3.2), which allows to produce a curved sheet in one pass without causing non bended plates ends.

For efficient production of rotor and stator plates of inductive position sensor the assembly of production line from these technological devices (see Fig. 3.2) was designed: decoiler, straightening device, actuating belt feeder, pneumatic shears with inclined tools, belt conveyer and four cylinders bending rolls.

Construction of production line (see Fig. 3.1) was projected in order to its operation can be secured by one production workman, which controls and chooses operation of CNC programme, takes individual roll bended rotor and stator plates of inductive position sensor from bending rolls and according to required technological procedure he composes them to rotor and stator complexes. Construction of production line was projected so that it is possible to move it by crane without necessity to dismantle and subsequently to put together and adjust the line.

To ensure the safety of production workers and people moving close to the production line, the security of production line by protective fence, that prevents the access to the workspace, was proposed. To replace the sheet coil the access through gate is allowed, which is guarded by a closing door safety switches.

\section{REFERENCES}

[1] ČADA, R. Tvářitelnost ocelových plechů: odborná knižní monografie. Lektorovali: L. Pollák a P. Rumíšek. 1. vyd. Ostrava: REPRONIS, 2001. 346 s. ISBN 80-86122-77-8.

[2] NOVOTNÝ, J. a LANGER, Z. Střiháni a další způsoby dělení kovových materiálů. 1. vyd. Praha: SNTL, 1980. 216 s. Bez ISBN.

[3] ČADA, R. Plošná tvářitelnost kovových materiálio. 1. vyd. Ostrava: VŠB-TUO, 1998. $90 \mathrm{~s}$. ISBN 80-7078-557-8.

[4] ZLÁMALÍK, J. Návrh produktivni technologie vystřihování plechů rotorů a statorů pro generátory: bakalářská práce. Ostrava: Vysoká škola báňská - Technická univerzita Ostrava, Fakulta strojní, 2009. 76 s.

[5] ZLÁMALÍK, J. Návrh technologie výroby plechu rotoru a statoru indukčního snímače polohy vystřihováním a zakružováním: diplomová práce. Ostrava: Vysoká škola báňská - Technická univerzita Ostrava, Fakulta strojní, 2011. 88 s.

[6] EVIN, E. Properties of steel-sheets with Fe-Zn coatings for automobile industry. Zsesyty naukowe, 2010, Vol. 16, No. 1, pp. 27-32. ISSN 1897-2683. 
Results in the contribution were achieved at solving of specific research project No. SP2013/63 with the name "Optimization of Flat and Volume Forming Technologies" (,Optimalizace technologií plošného a objemového tvářeni“) solved in year 2013 at the Faculty of Mechanical Engineering of VŠB - Technical University of Ostrava. 